
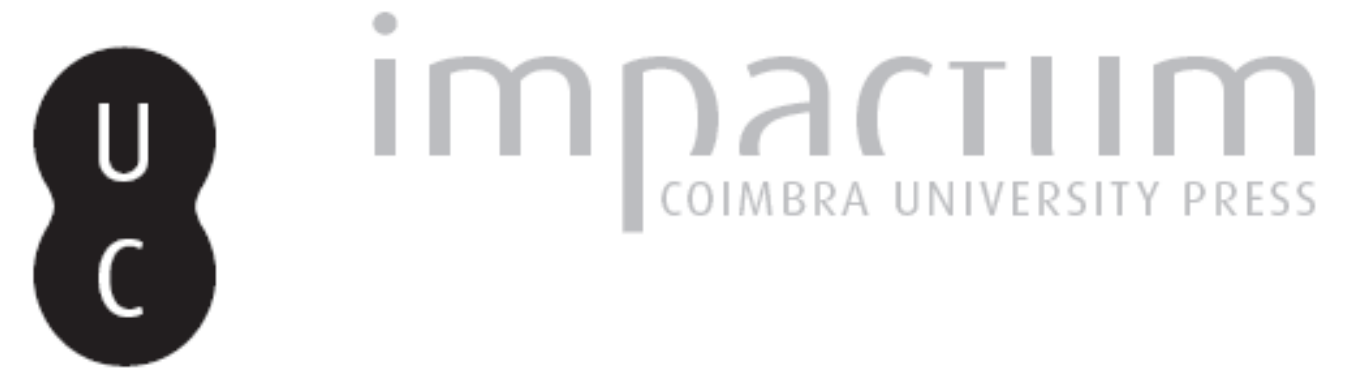

\title{
The scientific contribution of Leonor Vasconcelos Ferreira
}

Autor(es): $\quad$ Teixeira, Aurora A. C.; Silva, Sandra; Teixeira, Pedro

Publicado por: Faculdade de Economia da Universidade de Coimbra

URL persistente:

URI:http://hdl.handle.net/10316.2/25204

DOI:

DOI:http://dx.doi.org/10.14195/2183-203X_35_1

Accessed : $\quad$ 26-Apr-2023 11:17:31

A navegação consulta e descarregamento dos títulos inseridos nas Bibliotecas Digitais UC Digitalis, UC Pombalina e UC Impactum, pressupõem a aceitação plena e sem reservas dos Termos e Condições de Uso destas Bibliotecas Digitais, disponíveis em https://digitalis.uc.pt/pt-pt/termos.

Conforme exposto nos referidos Termos e Condições de Uso, o descarregamento de títulos de acesso restrito requer uma licença válida de autorização devendo o utilizador aceder ao(s) documento(s) a partir de um endereço de IP da instituição detentora da supramencionada licença.

Ao utilizador é apenas permitido o descarregamento para uso pessoal, pelo que o emprego do(s) título(s) descarregado(s) para outro fim, designadamente comercial, carece de autorização do respetivo autor ou editor da obra.

Na medida em que todas as obras da UC Digitalis se encontram protegidas pelo Código do Direito de Autor e Direitos Conexos e demais legislação aplicável, toda a cópia, parcial ou total, deste documento, nos casos em que é legalmente admitida, deverá conter ou fazer-se acompanhar por este aviso. 


\section{N॰TASEC}

\section{Recent debates on poverty and inequality}

A Special issue in memory of Leonor Vasconcelos Ferreira (1960-2008)

AURORA TEIXEIRA/THE SCIENTIFIC CONTRIBUTION OF LEONOR VASCONCELOS FERREIRA SANDRA SILVA/

PEDRO TEIXEIRA

CARLOS FARINHA RODRIGUES/ ISABEL ANDRADE

MONETARY POVERTY, MATERIAL DEPRIVATION AND CONSISTENT POVERTY IN PORTUGAL

JOANA AFONSO/ ISABEL MOTA/

MICRO CREDIT AND TERRITORY: PORTUGAL AS A CASE STUDY SANDRA SILVA

MARIA CIDÁLIA QUEIROZ/ MARIELLE GROS
SOCIAL INSERTION INCOME: THE CONTRIBUTION OF THE ASSOCIATION QUALIFICAR PARA INCLUIR 


\section{0 (III) $\bigcirc$} The Scientific Contribution of Leonor Vasconcelos Ferreira*

Aurora A.C. Teixeira / Sandra Silva / Pedro Teixeira CEF.UP, FE.UP; INESC Porto; OBEGEF / CEF.UP, FE.UP / CIPES, FE.UP abstract resumo / résumé

Despite her sadly short academic life, Leonor Vasconcelos Ferreira has left us a set of publications of noticeable scientific quality and explicitly social relevance, focusing on the study and measurement of poverty and income inequality. The present article briefly summarises the outcome of her work and the concerns underpinning it.
Não obstante a sua curta vida académica, Leonor Vasconcelos Ferreira deixa-nos um conjunto de publicações de óbvia qualidade científica e relevância social, centradas no estudo e mensuração do fenómeno da pobreza e da desigualdade do rendimento. O presente artigo resume o resultado do seu contributo científico e das suas preocupações.

Cependant sien tanne vie académique, Leonor Vasconcelos Ferreira nous laisse un ensemble de publications de qualité scientifique et une importance sociale évidente, qui sont centrés dans l'étude et la mensuration du phénomène de la pauvreté et de l'inégalité du revenu. Le présent article résume le résultat de sa contribution scientifique et de les préoccupations sous-jacentes au même.

JEL Classification: A10, D63.

\footnotetext{
* The present text is based on a previous text in Portuguese published in the book «O Que Sabemos Sobre a Pobreza em Portugal?», organized by Teixeira et al. (2010). We thank Vida Económica for the permission to publish the present version.
} 
"Questions are expressions of our interest in the world; they are at bottom valuations. »

Gunnar Myrdal, 1976: 13

\begin{abstract}
«Few people have studied poverty in Portugal better than Leonor Vasconcelos Ferreira. (...) Her articles (...) fruit of decades of work, and that statistical work, always marked by 'objectivity' and couched in academic jargon, tried to explain why Portuguese poverty is so 'chronic' and persistent and why it has handed down from parents to children. When we read Leonor Ferreira writings, we understand that at the core of the problem (...) are human development policies that can lead groups of particularly vulnerable poor people to assimilate values of education, social learning and preparation for the future.»
\end{abstract}

Pedro Lomba Diário de Notícias, August 14, 2008

\title{
1. Introduction
}

Remembering the work of Leonor Vasconcelos Ferreira and her contribution to the science of economics in Portugal, provides an opportunity to revisit her main research themes and to a brief reflection about research on poverty and inequality in Portugal.

Even a cursory analysis of Leonor Ferreira work highlights the fact that she sought throughout her career to consider, investigate, and analyse the issues she regarded as relevant, not only intellectually but also in terms of her convictions and beliefs. The quotation from Gunnar Myrdal at the top, written by that Leonor Vasconcelos in the introduction of her PhD thesis, is particularly enlightening. Despite her sadly short academic life, Leonor has left us a set of publications of obvious scientific quality and social relevance, focusing on the study and measurement of poverty and income inequality. In this text, we shall be looking at the outcome of this work and the concerns underpinning it.

\section{The complexity of poverty in Portugal - Measuring to improve understanding}

After several decades of divergence with the leading Western European economies, in the turn to the 1960s Portugal entered in a period of rapid economic growth that lasted until the 1990s, despite the turbulence caused by the democratic revolution of 1974 (Franco, 2008). This process was significantly boosted by the membership of the EU (in 1986) and promoted a significant catch-up in levels of per capita income, alongside major structural transformations that brought the Portuguese economy much closer to the level of its European counterparts.

Nevertheless, the belated spurt of economic growth and the pre-1970s emphasis on fiscal stability has delayed the development of the welfare state and redistribution policies. Thus, Portugal has lagged as regards the wave of inequality redistribution that characterised most of the Western world in the postwar decades (Atkinson, 2008). These themes became increasingly relevant in the Portuguese political and economic context of the late 1970s in which Leonor Ferreira started her training as an economist.

The scientific rigour and innovative nature of her work in measuring poverty are common threads running through all of Leonor Ferreira's studies and writings, stemming from the research begun in 1991 when she submitted a draft for her PhD thesis in economics to the Instituto Superior de 
Economia e Gestão of the Lisbon Technical University. Having concluded her thesis in 1997, the scientific and public importance of this work was recognised when she was awarded the Economic and Social Council (CES) prize in 1998, later published in book form under the title «A Pobreza em Portugal na Década de Oitenta» (Ferreira, 2000a).

As the author stated, the purpose of the study was to «systematically examine the methods of measuring income poverty" (Ferreira, 2000a: 305). Her perspective was to consider poverty in terms of the right to a minimum level of income, leading to a definition of the poverty line as the minimum income able to meet basic needs in Portuguese society at some point in time. This poverty line should, therefore, be regarded as a benchmark for the minimum income that the state could take as the right to citizenship and the minimum safety net for people unable to achieve a minimum level of resources from their own efforts.

The first results of this research were published in two articles in the journal Estudos de Economia in the early 1990s. The first one (Ferreira, 1992) examines the problems associated with measuring poverty. She discusses the relevance of three broad measures (headcount poverty rate, relative income gap and Foster's measure) to identify the incidence, depth and severity of poverty in Portugal in the 1980s. Using data provided by the Portuguese Statistical Office (INE) through household income and expenditure surveys (1980-81) and household budget surveys (1989-90), she found that there was a small decline in the poverty indicators and that a particularly high level of poverty persisted in Portugal in comparison with Western Europe. These results were especially worrying in light of the good performance of the country's economy in the second half of the decade.

The purposes of the study also allowed for the breakdown of the groups affected by poverty and thus the main socio-economic characteristics related to poverty could be singled out. Thus, in a second study (Ferreira, 1994), she concentrated on the issue of child poverty and sought to find the mechanisms by which poverty is transmitted in Portuguese society. Using the same statistical sources, the author confirmed the existence of severe poverty problems, now affecting the population under eighteen. This type of poverty is clearly linked to poor housing conditions and, above all, to school dropout rates and early working life, which contribute to the persistence of inter-generational poverty.

The final outcome of her PhD work was presented publicly in 1997 (and published in 2000). Leonor Vasconcelos started by explaining both the relevance of the economic study of poverty and its complexity. Thus, although she recognised that her study was confined to measuring poverty in monetary terms (inadequate income), she highlighted the relevance of robustly documenting the scale of this monetary poverty, given moreover its high correlation with other aspects of poverty and its impact on the related phenomena of inequality and social exclusion. ${ }^{1}$

Leonor Vasconcelos then examined the different ways of measuring poverty, paying particular heed to its representativeness in relation to the different aspects of monetary or income poverty and their possible input to building poverty indices. These measures had had significant developments based on the contributions of Amartya Sen, who had put forward a number of alternative proposals (for an overview, see Sen, 1982). Leonor Vasconcelos focused on the methodological problems associated with the different measures proposed and on their efficacy in gauging the concept of poverty adopted. Among the main issues discussed was the question of the concept of income, the unit of reference, and the scales of reference, and whether they were appropriate to the case of Portugal.

1. The experience gained with her Master's thesis played a part in her concern with rigour, in which Leonor Vasconcelos undertook a formalised analysis of the problems associated with measuring in spatial analysis (Ferreira, 1987). 
These methodological concerns were to feature prominently in Leonor Vasconcelos' analysis of the statistical information available in Portugal, on the basis of which monetary poverty could be studied. The author highlighted the quality and range of the surveys on household budgets, noting especially that they were countrywide and yielded a wealth of information about the living conditions of families, providing a better understanding of the social dynamics associated with monetary poverty.

Analysis of the data confirmed the preliminary results presented in 1992, in particular the existence (and persistence) of significant income poverty issues in Portugal throughout the 1980s. The detailed region-by-region study showed that the North came off worst, a result that was to have significant resonance in Leonor's later work. The breakdown by social groups also indicated that the incidence of poverty was worse in older age groups and households with very low education levels.

The importance of the connection between poverty and education was underscored in the study's conclusions. Leonor Vasconcelos stressed the strategic role of education and skills in combating poverty and social exclusion, insofar as they encourage better social integration through stable and successful inclusion in the labour market. She further noted that "the fight should concentrate essentially on the mechanisms whereby poverty and social exclusion are generated and transmitted, so as to achieve a deeper, regenerating transformation of the modus operandi of the social system», and to do so required the «mobilisation of public powers, of citizens and civil society, as well as of the poor themselves» (Ferreira, 2000a: 311).

This thorough study on poverty in Portugal would be further pursued in an analysis of low-paid employment, one of the factors most intricately linked to the incidence of poverty. In a jointly authored article with Graça Leão Fernandes (Ferreira and Fernandes, 1999), published in European Research in Regional Science, Leonor Vasconcelos studied the incidence and structure of low-paid work (where pay was only slightly above half the average wage of all wage earners). The study is based on Quadros do Pessoal, which have been an excellent source to examine a wide range of dimensions of Portugal's economic situation, including labour market trends, returns to skills and training, and wage discrimination.

The analysis covered the period from 1982 to 1992 and showed an increase in the incidence of this type of employment in the Portuguese economy, reaching almost 15 percentage points. The authors also concluded that, on average, women were nearly twice as affected as men. The groups with poor formal education and younger people seemed to be the most affected by high rates of low-paid work (with an upward tendency). This outcome was even more worrying since it contrasted with an increase in formal qualifications over the same period, especially in the younger age groups. But the authors concluded that this result was derived from increasing wage disparity in these age groups and between the more and less skilled workers. In both instances, formal qualification emerged as a successful personal strategy to reduce the risk of low wages.

The study involved a wide-ranging analysis of the microeconomic data underlying Quadros do Pessoal and revealed a complex picture of the incidence of low-paid work in Portugal. The analysis involved a comparison among firms and depicted a particularly unfavourable situation for very small firms. The breakdown by business sector revealed that the agriculture, forestry and fishing sector was the most affected by low wages, indicating that its incidence, already very high in 1982 , at $69 \%$, had risen 7 percentage points. At the other extreme, the sectors with a low incidence were generally capital intensive and technologically advanced (transport and communications; banking and insurance). Regionally, low-paid work accounted for nearly half the jobs in the North and Alentejo regions, although both regions with very distinctive features. The North is characterised by labour-intensive, low-tech industrialisation, whereas Alentejo suffers from a high level of desertification and low industrialisation. 


\section{Poverty and socioeconomic disparity - A regional viewpoint}

One of the main features of Portugal's belated and irregular process of economic development has been the persistence of strong regional disparities regarding income and welfare indicators. The increasing awareness of this problem has stimulated significant academic and political interest, and in recent decades we have observed various attempts to promote a better understanding of these regional inequalities and to formulate policies that could redress effectively those inequalities, notably through government expenditures and EU-funds (for an analysis see Pereira and Andraz, 2009).

The regional dimension on poverty and inequality, which had been exploited in Leonor Vasconcelos' earlier works, was to become more central in the following years. Her interest in regional issues was not new, otherwise Leonor would not have taken a master's in regional and urban planning at UTL (Ferreira, 1987), under supervision of Prof. Carlos Silva Ribeiro. Nor was this increasing focus on regional topics unrelated to her move from Lisbon to Porto, and her interest in studying local economic and social circumstances and the questions raised by poverty in the Porto area and the North Region.

Thus, in the early 2000s, Leonor developed a study with Carlos Farinha Rodrigues on the social situation in Portugal's North Region, which was supported by the North Regional Coordination and Development Commission (CCDRN). The preliminary results of this work were presented in 2001, and the final work was published in 2003. In addition, she collaborated in two of the most comprehensive and detailed studies in recent decades on the issue of housing in Porto, especially the social and urban problems of the municipal social housing neighbourhoods, where Leonor paid particular attention to the relationship between poverty and social housing. Both studies were undertaken in cooperation with the Porto City Hall (Pimenta, Ferreira, and Ferreira, 2001; and Pimenta et. al., 2001).

In the first work on A Distribuição do Rendimento, a Pobreza e o Papel das Políticas Redistributivas na Região do Porto (Ferreira and Rodrigues, 2003), which was part of a larger study on the social situation in the North Region of Portugal, Leonor Vasconcelos Ferreira and Carlos Farinha Rodrigues developed several approaches to assess and analyse the origin and composition of income. In particular, they gathered and organised evidence on the evolution of disparities in income distribution. This study also described the most pressing situations of deprivation and assessed the effects of state taxes and transfers on the inequality of income distribution, as well as the impact of implementing the guaranteed minimum wage (GMW) on reducing the extent and depth of poverty. Yet again we see the convergence of the two main features of her work: the concern with analysing urgent social issues, on the one hand; and the concern with tackling these complex topics with methodological rigour, on the other.

The analysis was based on the surveys of household budgets for 1989/90 and 1994/5. Examining the period 1990-95, the authors noted that poverty had worsened in the North Region, although not as markedly as for mainland Portugal overall. This is largely explained by the disparity in employment income. The study also showed that social transfers were the main factor in reducing inequality, with direct taxes also playing an important part. The recently introduced GMW also helped to equalise incomes and greatly improved the living conditions of the most vulnerable groups.

The authors found that the incidence and depth of poverty decreased during the period analysed, although they noted that the average intensity and severity of poverty had in fact worsened. Mapping the groups most affected by poverty in the North to some extent resembled what Leonor Vasconcelos had observed in previous work on mainland Portugal as a whole. Incidence was thus most significant in the rural and semi-urban areas, in the elderly, in large families, in single-parent families and in families with lower educational attainment. 
This research was also meant to support the establishment of social intervention strategies in the North Region. Leonor Vasconcelos and Carlos Farinha concluded emphatically from this 'poverty mapping' of the North Region that "only a profound intervention in training human resources, motivating education and training in younger generations, and the acquisition of new skills and qualifications in adults would make it possible to break with the poverty cycle and cut the chains by which intergenerational poverty is transmitted.» (Ferreira and Farinha, 2003: 75).

These conclusions converged with the results of the work carried out at the same time on the city of Porto. One study, in which Leonor Vasconcelos collaborated with Manuel Pimenta and José António Ferreira ( Pimenta, Ferreira, and Ferreira, 2001), reported that here the poverty rate was very high, with $38.6 \%$ of the resident families being affected at that time. The authors highlighted the multiple effects - economic, cultural, psychological - of poverty and the fact that poverty goes hand-in-hand with multiple problems, whose effects steadily build up. They noted the need for a multidimensional approach to the problems and solutions of poverty.

The analysis of the socioeconomic conditions of Porto's social housing neighbourhoods led them to press for a multidimensional view of poverty and social exclusion. They recommended multisectoral actions on the factors that impede integration, from prejudice and stigmatisation to scarce housing; from lack of qualifications to lack of opportunities; from stagnating in marginal lifestyles to overcoming such behaviour. The authors believed that profound changes in institutional practices were needed, involving the collective deployment of people, institutions and their agents to ensure the success of programmes to combat poverty and promote local social development.

Another study by these three authors, together with Alexandra Faria and Paula Pimentel, also looked at the problems of poverty in Porto (Pimenta, et al. 2001). A socioeconomic study was conducted on 'I/has'2 of Porto, producing a detailed portrayal of a population living in extremely precarious housing conditions. The study quantified and characterised this group of people, their income patterns and housing, and their problems, needs and aspirations. The section of the study developed by Leonor Vasconcelos (Chapter 5: «Income levels and the incidence of poverty") showed that, despite their meagre incomes, the residents in 'ilhas' (and other kinds of housing, also analysed) were, in social and economic terms, fully integrated in the employment and social security systems at the time. Again stressing the multidimensional nature of poverty, Leonor Vasconcelos Ferreira noted that vulnerability to poverty is linked to exclusion from the labour market and to unskilled jobs, generally associated with poor qualifications. She argued that «... facilitating access to decent housing (...) is a weapon in the fight for integration, and in the efforts for urban regeneration and cohesion.» (Pimenta, et al., 2001: 55).

The regional scale of her studies on poverty is apparent in two other works she published at the start of the 2000s. One of these studies, co-authored with Graça Leão Fernandes (Ferreira and Fernandes, 2000), analysed the trend in wage differences by gender in the labour market in the North, and compared it with the overall average. Once again using the data from Quadros de Pessoal, the authors found that there was a significant wage difference between men and women throughout the 1992-1997 period. Women were still over-represented in jobs with poorer social recognition and lower pay, for several reasons, particularly since they tended to have lower formal qualifications. But such differences persisted, even for identical skills and educational attainment, which led the authors to conclude that there were significant issues related with wage discrimination in the Portuguese labour market.

In 2002, Leonor Vasconcelos co-authored a paper with Jorge Bateira that looked at issues of regional policy and innovation in which social concerns were a feature. In their work "Questioning EU cohesion policy in Portugal: A complex system approach», published in 
European Urban \& Regional Studies, (Ferreira and Bateira, 2002) the authors examined the strategic behaviour of small and medium enterprises (SMEs) in their response to direct funding via Structural Funds for the North Region. They found that the firms' ability to develop their own capabilities independently is crucial for the development of depressed areas, rather than the provision of financial help. In terms of innovation policy, therefore, it would be particularly important for government authorities and firms to work together to make SMEs competitive and boost territorial development.

\section{The role of social policies in fighting poverty - the specific characteristics of Portugal}

One of the most significant features of Portugal's recent economic trajectory has been its growing European integration. This has had multiple and complex effects at the economic, political, cultural, and social levels. It has certainly played a role in the way research and policies regarding poverty have been developed in recent years, notably by adopting a much more comparative approach and by exploring the experiences of other European countries dealing with similar problems and policy aims (see Amaral and Neave, 2011). The growing internationalization of Portuguese research networks, with increasing short and long-term mobility of Portuguese researchers has also contributed significantly in this respect (see Patrício, 2010).

This growing international comparative approach has also become increasingly present in Leonor Vasconcelos's research on poverty, leading her to pay more attention in the final years of her academic activity to the specifics of Portugal from a European perspective, especially in comparison with other Southern European countries. Following on from her previous work, Leonor looked at the trend in other European countries and thus became particularly interested in analysing the dynamics of poverty and income inequality, and the most important factors in explaining their greater or lesser incidence in the Portuguese context.

In this context, her first work discussed vulnerability and poverty in Portuguese society in the 1990s (Ferreira, 2000a; Ferreira, 2002). Here Leonor used a longitudinal database produced by Eurostat that enabled her to use figures for Portugal in a comparative context, with other EU countries. The paper used the same approach as her earlier works and those of Carlos Farinha Rodrigues in their studies of material poverty and income disparity. The analysis suggests that conditions improved for the Portuguese with the lowest incomes in 1994-97, and this result was confirmed by the indicators employed to gauge dispersion, inequality, poverty and well-being.

A disaggregated analysis of the data allowed the impact of those improvements on the relative trend of certain groups to be evaluated. The elderly, for instance, seem to have benefited from the improvements, even though they tended to be more deprived than the population as a whole. Despite this positive tendency, the study indicated the persistence of significant regional differences, considerable income mobility (slightly in favour of descending relative mobility), and "a strong and enduring differentiation of income among the various socioeconomic categories» (Ferreira, 2000b: 16)

These somewhat conflicting trends led her to undertake a fresh study that examined the dynamics of income mobility and monetary poverty in Portugal and compare those results with the current state of policies against poverty and social exclusion (Ferreira, 2005). In this study, Leonor Vasconcelos once more used comparative figures for Europe, this time from the European Community Household Panel. The analysis indicated that income distribution in Portugal at the end of the 1990s was highly asymmetric in comparison with the data from the 15 countries belonging to the EU at the time. In addition, inertia in income distribution, the incidence of low incomes and the risk of poverty reached their highest levels in Portugal for the period, within the EU.

These results prompted the author to question the effectiveness of benefits systems in reducing inequality and poverty in Portugal. This problem was also seen in the persistently high number of chronic poor, i.e., those people who have simply never been able to overcome their lack of 
monetary resources. It also seems to have had a significant impact in terms of the intergenerational transmission of material poverty, which is another urgent and complex challenge for social policies.

In her last published works, Leonor Vasconcelos (Ferreira, 2008) tried to provide new tools to construct and legitimise social policies. This work recovers her multi-dimensional vision of poverty, set out in her doctoral thesis, based on an in-depth analysis of the social systems which sought to combine the measurement of inequality and material poverty with an analysis of social attitudes and values. Portugal tended to stand out for the wrong reasons as the country in the EU 15 with the highest and most persistent levels of poverty; it was also top among the Mediterranean countries, which as a group were characterised by poor social support within a weak and imperfect public system.

Leonor Vasconcelos Ferreira focused on the causes of the inefficiency of the 'Mediterranean system'. Some useful conclusions were drawn from the statistical analysis: the existence of relatively low levels of social spending and a prevalence of generous benefits for those in work. But she also observed that there were systems offering minimal, fragmented protection and social benefits, as well as fairly scarce and inefficient pensions that were badly targeted in terms of reducing poverty. Finally, these countries exhibited marked social and political inertia in relation to poverty and inequality. Given these cultural and institutional features of the Southern European countries, Leonor Ferreira clearly stressed the need to foster the conception of social policies, the building of security networks and the promotion of a fairer and more effective social security system; actions that would not merely rely on importing the better developed welfare measures in operation in northern Europe.

In this article, Leonor Ferreira also pursued the task of systematising the causes of and seeking solutions for the phenomena of poverty. This was essential, as the author made clear, so as to place the issue of poverty at the heart of the social concerns that demanded political priority. The research focus here was to analyse how social policies address the enduring phenomenon of poverty observed in southern European countries in general, and in Portugal in particular. The author believed that studying public social systems in the relatively less economically-developed European nations (Greece, Italy, Portugal and Spain), whose systems are more recent than the European Union (15) average, could be very important for both the countries in question and new members of the EU.

\section{Final remarks}

For nearly twenty years, Leonor Vasconcelos was devoted to the theoretical and empirical study of issues related to income dynamics, persistent poverty and social policies in Portugal, concentrating particularly on the methods of measuring poverty. Her unremitting interest in these topics led her to produce a significant body of work on poverty and income disparity in Portugal, and this has proved a relevant contribution to both economics and to other related social sciences.

Even though economics is often criticised today for being too abstract and formalised, with a tendency to distance itself from socially and politically relevant issues, the work of Leonor Vasconcelos is remarkable for its constant concern with connecting with the surrounding economic and social reality and for the attempt to find answers to the questions raised by that reality. This hallmark is equally obvious, whether more globally in the study of poverty in Portugal and in the analysis of the effectiveness of the social measures that aimed to alleviate the problem; whether more focused at regional and urban level, with her growing interest in studying poverty in the North Region and the city of Porto, areas which, although not her native territory, steadily became the priority regions for her intellectual and social focus.

This interest in studying problems relevant to the economic and social surroundings also led her to undertake research that was quite often based on cooperation with political and institutional 
actors. They recognised in Leonor an exceptional interlocutor to analyse and appraise the problems of poverty, inequality and housing, at national, regional and municipal level. The work of Leonor Vasconcelos prioritised discussion with such public authorities so as to provide a better insight into the realities and thus be able to devise policies better suited to minimising the effects of poverty and inequality.

There are, without any doubt, differences between scientific discourse and public intervention or social reflection, and Leonor Vasconcelos saw to it that the intellectual rigour she brought to her work retained these two independent, yet interlinked, aspects. We think, however, that she believed that scientific discourse could not be constructed on the presumption that individuals can neutralise their convictions and subjectivity. Maybe it would have been easier to make this distinction if she had chosen other research topics, but she chose to study, as an economist, topics that tried to respond to her intellectual and ethical concerns.

Finally, a noteworthy aspect of Leonor Vasconcelos's intellectual legacy is that she went against the tacit and tactical thinking that a university neither can nor should be a place where political, philosophical and religious convictions are assumed. Leonor tried to do so in a manner that respected the differences coexisting in the university, but without self-inhibition. In doing so, she made her loyalty to her principles abundantly clear and showed that a university can be a place where we can live the fullness of who we are, without constraint or intolerance. 
Amaral, A. and Neave, G. (2011), A Nation and a Generation: Higher Education in Portugal (1974-2010), Dordrecht, Springer.

Atkinson, A. B. (2008), The Changing Distribution of Earnings in OECD Countries, Oxford, Oxford University Press.

Ferreira, L.V. (1987), Teoria da Medida na Análise Espacial: Uma exposição, Dissertação de Mestrado, Lisboa: ISEG-UTL Ferreira, L.V.

Ferreira, L.V. (1992), «Pobreza em Portugal: Variação e decomposição de medidas de pobreza a partir dos orçamentos familiares de 1980-81 e 1989-90», Estudos de Economia, 12, 377-393.

Ferreira, L.V. (1994), «Pobreza Infantil em Portugal na Década de Oitenta», Estudos de Economia, 14, 451-464.

Ferreira, L.V. (1997), A Pobreza em Portugal na Década de Oitenta, Tese de Doutoramento, Lisboa, ISEG, Universidade Técnica de Lisboa.

Ferreira, L.V. (2000a), A Pobreza em Portugal na década de oitenta, Lisboa, Conselho Económico e Social.

Ferreira, L.V. (2000b), Distribuição do rendimento e pobreza: a Região Norte no contexto nacional entre 1990 e 1995, Estatísticas \& Estudos Regionais, 24, 17-30.

Ferreira, L.V. (2002), Vulnerabilidade e Pobreza: A situação em Portugal em meados da década de 90, Sociedade e Trabalho, 16, 35-52.

Ferreira, L.V. (2005), Dinâmica de rendimentos, persistência da pobreza e políticas sociais em Portugal, Sociedade e Trabalho, 26, 101-117.

Ferreira, L.V. (2008), Persistent Poverty: Portugal and the Southern European Welfare Regime, European Societies, 10, 49-72.

Ferreira, L.V.; Bateira, J. (2002), Questioning EU cohesion policy in Portugal: A complex systems approach, European Urban and Regional Studies, 9, 297-314.

Ferreira, L.V.; Fernandes, G.L. (1999), Low-wages in Portugal: Social dimension and recent evolution, European Research in Regional Science, 9, 208-220.

Ferreira, L.V.; Fernandes, G.L. (2000), Gender Differentials In Labour Markets - The Case of Portugal, ERSA conference papers, August 2000, European Regional Science Association.

Ferreira, L.V.; Rodrigues, C.F. (2003), A Distribuição do Rendimento, a Pobreza e o Papel das Políticas Redistributivas na Região do Norte, Porto, Comissão de Coordenação da Região do Norte.

Franco, F. (ed.) (2008), Challenges Ahead for the Portuguese Economy, Lisbon, ICS.

Patrício, M. T. (2010) Science policy and the internationalisation of research in Portugal, Journal of Studies in International Education, 14, 161-182.

Pereira, A. M and Andraz, J. (2009), Public Investment and Regional Asymmetries, in Lains, P. (Ed.) Borderless: The New Horizons of the Portuguese Economy, pp. 229-255.

Pimenta, M., Ferreira, J.A., Ferreira, L.V. (2001), Estudo Socioeconómico da Habitação Social Porto, Porto, Câmara Municipal do Porto.

Pimenta, M., Ferreira, J.A., Ferreira, L.V., Faria, A., Pimentel, P. (2001), As 'Ilhas' do Porto Estudo Socioeconómico, Porto, Câmara Municipal do Porto.

Sen, A. (1982), Choice, Measurement, and Poverty, Oxford, Blackwell. 